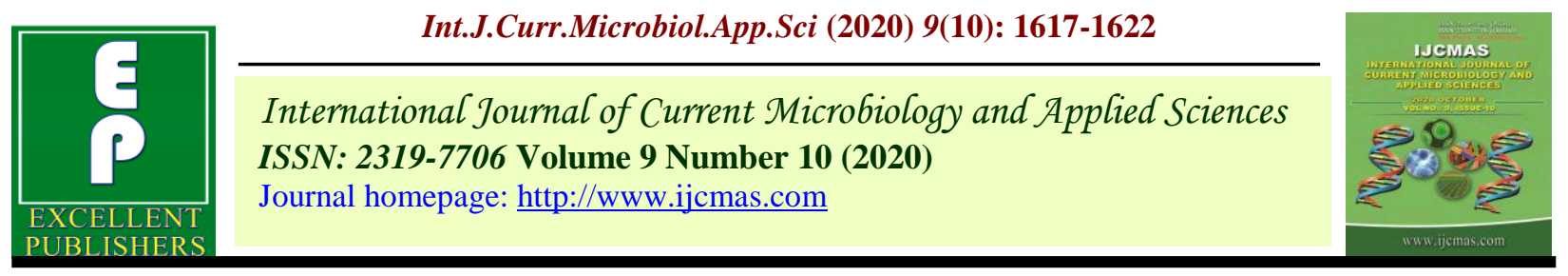

Original Research Article

https://doi.org/10.20546/ijcmas.2020.910.193

\title{
Response of Fly Ash and Nitrogen on Production of Toria (Brassica campestris var. Toria)
}

\author{
Hardeep Singh Dhillon and Balwinder Singh Dhillon*
}

College of Agriculture, Guru Kashi University, Talwandi Sabo, Punjab, India

*Corresponding author

\section{Keywords}

Fly ash, Nitrogen,

Seed yield,

Siliquae, Stover

yield and Toria

Article Info

Accepted:

12 September 2020

Available Online:

10 October 2020

\section{A B S T R A C T}

A field experiment entitled "Response of fly ash and nitrogen on production of toria (Brassica campestris var. toria)" was conducted during rabi 2018-19 at Research Farm, Guru Kashi University, Talwandi Sabo, Bathinda (Punjab). The experiment was laid out in split plot design comprising three fly ash levels viz., control (0 t/ha), 5 and $10 \mathrm{t} / \mathrm{ha}$ in main plots and four levels of nitrogen viz., $0,37.5,62.5$ and $87.5 \mathrm{~kg}$ N/ha in sub plots. The results showed that the highest plant growth viz., plant height and leaf area index, number of primary branches/plant and number of secondary branches/plant and yield attributing characters viz., number of siliquae/plant, siliquae length, and 1000-seed weight and stover yield was recorded in fly ash @ 10 t/ha which was significantly higher over the control and fly ash @ 5 t/ha. Fly ash @ 10t/ha resulted in 11.5 and 5.51\% higher seed yield than control and fly ash @ $5 \mathrm{t} / \mathrm{ha}$, respectively. Increasing nitrogen levels increased the plant height, leaf area index, number of primary branches and number of secondary branches significantly up to $87.5 \mathrm{~kg} \mathrm{~N} / \mathrm{ha}$. Significantly higher values of seed yield, stover yield and biomass yield were obtained in nitrogen @ $87.5 \mathrm{~kg} / \mathrm{ha}$ than $0,37.5$ and $62.5 \mathrm{~kg} / \mathrm{ha}$. Nitrogen @ 87.5 kg N/ha recorded 39.2, 17.6 and 2.8\% higher seed yield than control, 37.5 and $62.5 \mathrm{~kg} \mathrm{~N} / \mathrm{ha}$, respectively. The highest seed yield (12.68 q/ha) was recorded in fly ash @ 10 t/ha with N @ 35 kg/ha.

\section{Introduction}

Toria (Brassica campestris var. toria) belongs to the family cruciferae popularly known as Indian rape and is an important rabi season oilseed crop of North-India. It is second most important edible oilseed crop after groundnut, accounts nearly $30 \%$ of the total oilseeds production in India. India is one of the largest rape seed growing countries in the world, occupying the first rank in area and second in production next to China. Crop production largely depends on cultivation of high yielding cultivars and need based application of nutrients. Nitrogen is the most important nutrient, and being a constituent of protoplasm and protein, it is involved in several metabolic processes that strongly influence growth, productivity and quality of crops (Kumar et al., 2000). Fly ash is a coal combustion residue generated from thermal power plants during burning of coal. It is the finely dispersed solid waste consisting of partially or completely burnt or un-burnt 
particles of carbon. When coal is burnt to generate heat, the residue contains fly ash and bottom ash in about $80 \%$ and $20 \%$ respectively. The mineralogical, physical and chemical properties of fly ash depend on the combustion, type of emission control devices, storage, and handling methods. Formation of fly ash depends on the ash content of coal. Indian coal used in power plants generally of low quality and has very high ash content (35$45 \%$ ). Fly ash has tremendous potential as a nutrient supplement, has similar physicochemical properties with soil, and is the treasure of trace elements that are readily available to the crop when mixed with the soil. Coal fly ash is enriched with $\mathrm{CaO}, \mathrm{MgO}$, $\mathrm{SiO}_{2}$ and $\mathrm{Fe}-\mathrm{Mn}$ oxides. Coal fly ash because of this alkaline $\mathrm{pH}$, available nutrients, particle size increases soil $\mathrm{pH}$ and the concentrations of most macro and micronutrients in the soil and also improves the soil texture and moisture holding capacity.

Thus keeping these points in view present experiment "Response of fly ash and nitrogen on production of toria (Brassica campestris var. toria)" was undertaken to study the effect of fly ash and nitrogen on the growth and seed yield of toria.

\section{Materials and Methods}

The present investigation entitled "Response of fly ash and nitrogen on production of toria (Brassica campestris var. toria)" was conducted at Guru Kashi University, Talwandi Sabo (Bathinda). It is situated between $29.99^{\circ} \mathrm{N}$ latitude and $75.08^{\circ} \mathrm{E}$ longitude with an altitude of 252 meters above the mean sea level. The experimental site belongs to sub-tropical semi-arid climate having extreme winters and summers. The experimental site belongs to semi-arid climate, where both summers and winters are acute. A maximum temperature of about $45^{\circ} \mathrm{C}$ is very common during summer, while freezing temperature accompany by frost happening may be in the months of December and January. The monsoon season normally starts from the first week of July. However, a few showers received during winter season also. The temperature and rainfall both were found to be optimum for cotton crop.

The soil was slightly alkaline $(\mathrm{pH} 8.60)$ with normal electrical conductivity $\left(0.16 \mathrm{dSm}^{-1}\right)$. The soil was medium in organic carbon content $(0.22 \%)$. The available nitrogen (130.0 $\mathrm{kg} \mathrm{ha}^{-1}$ ) was low, whereas the available phosphorus (18.4 $\mathrm{kg} \mathrm{ha}^{-1}$ ) and available potassium $\left(220.0 \mathrm{~kg} \mathrm{ha}^{-1}\right)$ were both medium. The experiment was laid out in split plot design with three replications. The treatments comprised of three levels of fly ash $(0,5$ and $\left.10 \mathrm{t} \mathrm{ha}^{-1}\right)$ and four levels of nitrogen $(0,37.5$, 62.5 and $87.5 \mathrm{~kg} \mathrm{~N} / \mathrm{ha}$ ).

The height $(\mathrm{cm})$ of five randomly tagged plants was measured at maturity. The branches which were counted on five tagged plants and average value were recorded. Total number of siliquae/plant was counted on five randomly selected plants in each plot. Five randomly selected siliquae were picked and seeds were counted. Seeds obtained after threshing of dried produce per net plot was cleaned, dried and weighed to give seed yield per plot. Seed yield was computed as $\mathrm{kg} / \mathrm{ha}$.

\section{Results and Discussion}

\section{Growth parameters of toria}

There was non-significant effect of fly ash on the plant height of toria (Table 1). The plant height was found maximum in fly ash @10 ton/ha $(150.4 \mathrm{~cm})$ followed by fly ash @ 5 ton/ha $(143.6 \mathrm{~cm})$ and control $(140.8 \mathrm{~cm})$. The present results are similar to the findings of Dash et al., (2017) observed the effect of fly ash amendment on shoot length of toria revealed that the length of shoot were 
maximum in the fly ash amendment as compared to control. Critical study data revealed that plant height increases with increase in nitrogen level at maturity and the tallest plants were found in $62.5 \mathrm{~kg} \mathrm{~N} / \mathrm{ha}$ which was statistically at par with $87.5 \mathrm{~kg}$ $\mathrm{N} / \mathrm{ha}$ and significantly higher than other nitrogen levels. The reason behind is that the shoot elongation continued to increase with the age of the plants.

Leaf area index was highest in fly ash @ 10 ton/ha which was significantly higher than control and fly ash@ 5 t/ha (Table 1). Leaf area index increased significantly with the increase in nitrogen levels. Highest leaf area index was observed in treatment having 87.5 $\mathrm{kg} \mathrm{N} / \mathrm{ha}$, which was significantly higher than control and $37.5 \mathrm{~kg} \mathrm{~N} / \mathrm{ha}$ but it was statistically at par with $62.5 \mathrm{~kg} \mathrm{~N} / \mathrm{ha}$. The increase in leaf area index was due to increase in size of leaf. Plant height had a cumulative effect on increasing the leaf area index.

Maximum number of primary branches was observed in fly ash @ 10 t/ha (8.42) which was significantly higher than fly ash @ 0 (control) and 5 t/ha (Table 1). Minimum number of primary branches (7.22) was observed in control crop. Application of fly ash in the soil returns most of the nutrients and helps to conserve soil nutrient reserves in the long term. Application of $87.5 \mathrm{~kg} \mathrm{~N} / \mathrm{ha}$ gave the highest number of primary branches per plant (8.79), which were significantly higher than control, 37.5 and $62.5 \mathrm{~kg} \mathrm{~N} / \mathrm{ha}$. Increased on number of primary branches per plant with higher doses of nitrogen were probably due to stimulatory effect of nitrogen on branches through cytokines synthesis, resulting into more number of primary branches.

Maximum number of secondary branches per plant (11.0) was observed in fly ash @ 5 t/ha (Table 1). Minimum number of secondary branches per plant (10.1) was observed in control plots of fly ash. Application of fly ash in the soil returns most of the nutrients and helps to conserve soil nutrient reserves in the long term. Data clearly indicated that on number of secondary branches per plant increases with increase in nitrogen level. Application of $87.5 \mathrm{~kg} \mathrm{~N} / \mathrm{ha}$ gave the highest number of secondary branches per plant which was significantly higher than other nitrogen levels viz., $0,37.5$ and $62.5 \mathrm{~kg} \mathrm{~N} / \mathrm{ha}$. Increased on number of secondary branches per plant with higher doses of nitrogen were probably due to stimulatory effect of nitrogen on branches through cytokines synthesis, resulting into more number of secondary branches per plant.

\section{Yield attributes of toria}

Maximum number of siliquae per plant was observed in fly ash @ 10 t/ha (41.3), which was significantly higher than control (39.7) and fly ash @ 5 t/ha (40.8) (Table 2). While, minimum number of siliquae per plant was observed in control crop. Application of fly ash in the soil returns most of the nutrients and helps to conserve soil nutrient reserves in the long term. Application of $87.5 \mathrm{~kg} \mathrm{~N} / \mathrm{ha}$ gave the highest number of siliquae per plant (42.3) which was significantly higher than control and $37.5 \mathrm{~kg} \mathrm{~N} / \mathrm{ha}$ and it was statistically at par with $62.5 \mathrm{~kg} \mathrm{~N} / \mathrm{ha}$ (42.3). Increased on number of siliquae per plant with higher doses of nitrogen were probably due to stimulatory effect of nitrogen on siliquae through cytokines synthesis, resulting into number of siliquae per plant.

Application of fly ash had significant effect on length of siliquae (Table 2). The higher length of siliquae was observed in fly ash @ 10 ton/ha $(5.35 \mathrm{~cm})$, which was significantly higher than control $(5.20 \mathrm{~cm})$ and fly ash @ 5 t/ha $(5.28 \mathrm{~cm})$. Length of siliquae significantly increases with the increasing 
levels of nitrogen. Application of $87.5 \mathrm{~kg}$ $\mathrm{N} / \mathrm{ha}$ gave the highest length of siliquae (5.48 $\mathrm{cm}$ ), which were significantly higher than control and $37.5 \mathrm{~kg} \mathrm{~N} / \mathrm{ha}$ and it was statistically at par with $62.5 \mathrm{~kg} \mathrm{~N} / \mathrm{ha}$. Similar results were also recorded by Singh and Brar (1999).

Maximum number of seeds/siliquae (21.6) was observed in fly ash @ $10 \mathrm{t} / \mathrm{ha}$ which was significantly higher than control (17.4) and fly ash @ 5 t/ha (19.0) (Table 2). Minimum number of seeds/siliquae was observed in control treatment. Application of fly ash in the soil returns most of the nutrients and helps to conserve soil nutrient reserves in the long term and improve physical properties of soil. Application of $87.5 \mathrm{~kg} \mathrm{~N} / \mathrm{ha}$ gave the highest number of seeds/siliquae (22.5) which was significantly higher than control (16.1), 37.5 $\mathrm{kg} \mathrm{N} / \mathrm{ha}(18.2)$ and $62.5 \mathrm{~kg} \mathrm{~N} / \mathrm{ha}(20.4)$. Increased on number of seeds/siliquae with higher doses of nitrogen were probably due to stimulatory effect of nitrogen on number of grain.

Table.1 Effect of different levels of fly ash and nitrogen on growth parameters of toria

\begin{tabular}{|c|c|c|c|c|}
\hline Treatment & $\begin{array}{c}\text { Plant height } \\
(\mathbf{c m})\end{array}$ & Leaf area index & \multicolumn{1}{|c|}{$\begin{array}{c}\text { Number of } \\
\text { primary } \\
\text { branches/plant }\end{array}$} & $\begin{array}{c}\text { Number of } \\
\text { Secondary } \\
\text { branches/plant }\end{array}$ \\
\hline Fly ash (t ha $\left.\mathbf{~}^{-1}\right)$ & & & & \\
\hline $\mathbf{0}$ & 140.8 & 1.66 & 7.22 & 10.1 \\
\hline $\mathbf{5}$ & 143.6 & 1.67 & 7.50 & 11.0 \\
\hline $\mathbf{1 0}$ & 150.4 & 1.79 & 8.42 & 10.6 \\
\hline LSD (P=0.05) & NS & 0.08 & 0.20 & \\
\hline Nitrogen levels (kg N/ha) & & & & \\
\hline $\mathbf{0}$ & 113.3 & 1.28 & 5.78 & 10.7 \\
\hline $\mathbf{3 7 . 5}$ & 129.3 & 1.72 & 8.18 & 11.1 \\
\hline $\mathbf{6 2 . 5}$ & 170.6 & 1.88 & 8.11 & 11.6 \\
\hline $\mathbf{8 7 . 5}$ & 166.6 & 1.95 & 8.79 & 0.5 \\
\hline LSD (P=0.05) & 9.5 & 0.12 & 0.58 & \\
\hline
\end{tabular}

Table.2 Effect of different levels of fly ash and nitrogen on yield attributing characters of toria

\begin{tabular}{|c|c|c|c|c|}
\hline Treatment & $\begin{array}{c}\text { Number of } \\
\text { siliquae/plant }\end{array}$ & $\begin{array}{c}\text { Length of } \\
\text { siliquae (cm) }\end{array}$ & $\begin{array}{c}\text { Number of } \\
\text { seeds/siliquae }\end{array}$ & $\begin{array}{c}\text { 1000-seed } \\
\text { weight } \mathbf{( g )}\end{array}$ \\
\hline Fly ash (t ha $\mathbf{~}^{-\mathbf{1}}$ ) & & & & \\
\hline $\mathbf{0}$ & 39.7 & 5.20 & 17.4 & 4.32 \\
\hline $\mathbf{5}$ & 40.8 & 5.28 & 19.0 & 4.41 \\
\hline $\mathbf{1 0}$ & 41.3 & 5.35 & 21.6 & 4.50 \\
\hline LSD (P=0.05) & 0.3 & 0.05 & 0.8 & NS \\
\hline Nitrogen levels (kg N/ha) & & & 4.29 \\
\hline $\mathbf{0}$ & 37.9 & 4.94 & 16.1 & 4.40 \\
\hline $\mathbf{3 7 . 5}$ & 40.3 & 5.24 & 18.2 & 4.42 \\
\hline $\mathbf{6 2 . 5}$ & 41.8 & 5.44 & 20.4 & 4.51 \\
\hline $\mathbf{8 7 . 5}$ & 42.3 & 5.48 & 22.5 & 0.11 \\
\hline LSD (P=0.05) & 0.6 & 0.10 & 0.12 & \\
\hline
\end{tabular}


Table.3 Seed yield of toria as influenced by different fly ash and nitrogen levels

\begin{tabular}{|c|c|c|c|c|c|}
\hline \multirow{2}{*}{$\begin{array}{c}\text { Fly ash } \\
\text { doses (t/ha) }\end{array}$} & \multicolumn{5}{|c|}{ Seed yield (q/ha) } \\
\cline { 2 - 6 } & Control & $\mathbf{3 7 . 5}$ & $\mathbf{6 2 . 5}$ & $\mathbf{8 7 . 5}$ & Mean \\
\hline Control & 7.36 & 9.58 & 11.22 & 10.94 & 9.78 \\
\hline $\mathbf{5}$ & 8.64 & 9.90 & 11.39 & 11.42 & 10.34 \\
\hline $\mathbf{1 0}$ & 9.18 & 10.31 & 11.47 & 12.68 & 10.91 \\
\hline Mean & 8.39 & 9.93 & 11.36 & 11.68 & 10.34 \\
\hline $\mathbf{C D}(\mathbf{p = 0 . 0 5})$ & Fly ash levels (F): $\mathbf{0 . 2 0}$ Nitrogen levels $(\mathbf{N}): \mathbf{0 . 5 8}$ & Interaction $(\mathbf{F} \times \mathbf{N}): \mathbf{0 . 4 1}$ \\
\hline
\end{tabular}

The highest 1000-seed weight (4.50 g) was recorded in fly ash @ 10 t/ha. However, 1000seed weight significantly increased with the increasing levels of nitrogen (Table 2). Application of nitrogen @ $87.5 \mathrm{~kg} \mathrm{~N} / \mathrm{ha}$ gave the highest 1000 -seed weight $(4.51 \mathrm{~g})$ which was statistically at par with $62.5 \mathrm{~kg} \mathrm{~N} / \mathrm{ha}$ and significantly higher than control and $37.5 \mathrm{~kg}$ N/ha.

\section{Productivity of toria}

The highest seed yield was observed in fly ash @ 10 t/ha (10.91 q/ha), which was significantly higher than control (9.78 q/ha) and fly ash@ @ t/ha (10.34 q/ha) (Table 3). Fly ash @ 10t/ha resulted in 11.5 and $5.51 \%$ higher seed yield than control and fly ash @ 5 t/ha, respectively. This may be due to increasing the yield attributes characters with the application of fly ash resulted in more seed yield. Minimum seed yield was observed in control treatment. Singh and Singh (1986) reported similar results for cotton and wheat grain yield with $20 \%$ fly ash which increased $\mathrm{N}, \mathrm{P}$ and $\mathrm{K}$ nutrients and increased the growth and grain yield. The increase in plant height, number of branches/plant, number of siliquae/plant and 1000-seed weight may be attributed to better moisture condition, nutrient absorption by the plant under fly ash application. Application of $87.5 \mathrm{~kg} \mathrm{~N} / \mathrm{ha}$ gave the highest seed yield (11.68 q/ha), which was statistically at par with $62.5 \mathrm{~kg} \mathrm{~N} / \mathrm{ha}(11.36$ $\mathrm{q} / \mathrm{ha}$ ) and significantly higher than control
(8.39 q/ha) and $37.5 \mathrm{~kg}$ N/ha (9.93 q/ha). Nitrogen@87.5 kg N/ha recorded 39.2, 17.6 and $2.8 \%$ higher seed yield than control, 37.5 and $62.5 \mathrm{~kg} \mathrm{~N} / \mathrm{ha}$, respectively. The minimum seed yield was recorded in control treatment. Higher seed yield obtained with application of $87.5 \mathrm{~kg} \mathrm{~N} / \mathrm{ha}$ might be attributed to better growth as well as yield contributing characters as significantly higher plant height, leaf area index, number of primary and secondary branches, higher number of seeds per siliquae, siliquae length and 1000-seed weight, which ultimately contributed towards higher seed yield. Increased in seed yield with higher doses of nitrogen were probably due to stimulatory effect of nitrogen on seed yield. These results collaborates the reports of Singh and Meena (2003) observed significant increase in grain, stover and dry matter yield with increasing $\mathrm{N}$ doses up to $50 \mathrm{~kg} \mathrm{~N} / \mathrm{ha}$. The maximum seed yield (12.68 q/ha) was recorded in fly ash @10 t/ha with N @ 87.5 $\mathrm{kg} / \mathrm{ha}$, while the minimum seed yield (7.36 $\mathrm{q} / \mathrm{ha}$ ) was recorded in fly ash @ $0 \mathrm{t} / \mathrm{ha}$ with $\mathrm{N}$ @ $0 \mathrm{~kg} / \mathrm{ha}$.

It can be concluded that fly ash @ 10 t/ha was found to be most effective in toria for achieving higher yield in toria crop. Fly ash @ 10t/ha resulted in 11.5 and $5.51 \%$ higher seed yield than control and fly ash @ 5 t/ha, respectively. Among different levels of nitrogen, significantly higher values of seed yield was obtained in nitrogen @ $87.5 \mathrm{~kg} / \mathrm{ha}$ than $0,37.5$ and $62.5 \mathrm{~kg} / \mathrm{ha}$. Nitrogen@87.5 
$\mathrm{kg} \mathrm{N} /$ ha recorded 39.2, 17.6 and 2.8\% higher seed yield than control, 37.5 and $62.5 \mathrm{~kg}$ $\mathrm{N} / \mathrm{ha}$, respectively. The highest seed yield (12.68 q/ha) was recorded in fly ash @ 10 t/ha with N@87.5 kg/ha.

\section{References}

Dash, S., Sahoo, S. and Sahoo, M. (2009). Effect of fly ash on growth and yield of mustard. International Journal of Applied Environmental Sciences pp. 1617-1629.

Kumar D, Singh S, Sharma S N and Shivay Y S (2000) Relative efficiency of urea and dicyandiamide-blended urea on mustard (Brassica juncea) varieties. Indian J Agron 45: 179-83.

Singh A and Meena N L (2003) Effect of nitrogen and sulphur levels on the oil and protein yield of mustard (Brassica juncea). Ann Agric Res 24: 368-71.

Singh S P and Singh V (2005) Effect of nitrogen, sulphur and zinc on Indian mustard (Brassica juncea). Indian $J$ Agric Sci 75: 828-30.

Singh T and Brar J S (1999) Effect of nitrogen and phosphorus application on seed yield of Indian mustard (Brassica juncea Coss). Ann Biol 15: 123-24.

\section{How to cite this article:}

Hardeep Singh Dhillon and Balwinder Singh Dhillon. 2020. Response of Fly Ash and Nitrogen on Production of Toria (Brassica campestris var. Toria). Int.J.Curr.Microbiol.App.Sci. 9(10): 1617-1622. doi: https://doi.org/10.20546/ijcmas.2020.910.193 